\title{
Membangun E-commerce Spare Parts Mobil pada Toko Aneka Jaya Motor
}

\author{
Sodik Nurhidayat ${ }^{1)}$, Muhammad Rusli ${ }^{2)}$ \\ Sistem Informasi, Fakultas Industri Kreatif Institut Teknologi dan Bisnis Kalbis \\ Jalan Pulomas Selatan Kav. 22, Jakarta Timur, 13210 \\ Email: sodikidoss@gmail.com \\ Email: muhammad.rusli@kalbis.ac.id
}

\begin{abstract}
Aneka Jaya Motor is company engaged in the business of selling car spare parts in Bekasi. At present Aneka Jaya Motor shop is only a shop, so the buying and selling process only occurs in the shop. Iin the current system there are many obstacles, such as the difficulty of promotion Aneka Jaya Motor goods to many customers, because so far the bidding and transactions have been done manually, which only relies on the buyer to come directly to the store. In conducting this research, the type of research use is qualitative research with the research method used in this research is Waterfall with system requirements, system analysis, system design with UML modelling and system implementation using PHP and MySQL and tested using the blackbox testing method. The results in this study are the creation of e-commerce information systems for selling car spare parts based website at Aneka Jaya Motor store that helps the sales process and makes it easy to transact long distances with Aneka Jaya Motor customers.
\end{abstract}

Keywords: e-commerce, mysql, php, uml, website

\begin{abstract}
Abstrak: Aneka Jaya Motor adalah satu perusahaan yang bergerak di bidang usaha penjualan spare parts mobil di Bekasi. Saat ini toko Aneka Jaya Motor hanya berupa toko saja, sehingga proses jual beli hanya terjadi di toko saja. Dalam sistem yang berjalan terdapat banyak kendala seperti sulitnya mempromosikan barang Aneka Jaya Motor ke banyak pelanggan, karena selama ini penawaran dan transaksi dilakukan secara manual yaitu hanya mengandalkan pembeli harus datang langsung ke toko. Dalam melakukan penelitian ini, metode penelitian yang digunakan dalam penelitian ini yaitu Waterfall dengan tahapan kebutuhan sistem, analisis sistem, perancangan sistem menggunakan pemodelan UML dan implementasi sistem menggunakan PHP dan MySQL dan diuji menggunakan metode pengujian blackbox. Tujuan dalam penelitian ini adalah membangun e-commerce sistem informasi penjualan spare parts mobil pada toko Aneka Jaya Motor berbasis website yang membantu proses penjualan dan mempermudah bertransaksi jarakjauh dengan pelanggan Aneka Jaya Motor.
\end{abstract}

Kata kunci: e-commerce, mysql, php, uml, website

\section{PENDAHULUAN}

Seperti yang diketahui bersama bahwa internet sudah tidak asing lagi bagi masyarakat luas. Banyak informasi yang dapat tersebar luas melalui internet dan dapat mengakses internet tanpa batas. Semua umur dapat menggunakan internet, mulai dari anakanak, remaja, dan orang dewasa sekalipun dapat menggunakan internet. Untuk dapat menggunakan internet sangatlah mudah, saat ini banyak sekali warnet beredar dimana-mana sehingga dapat datang dan langung menggunakannya. Saat ini banyak perusahaan yang menggunakan aplikasi berbasis web untuk menunjang penjualan produk-produk yang ditawarkan. Aplikasi berbasis web digunakan karena dapat diisi dengan konten-konten menarik dan dapat disesuaikan dengan informasi yang diperlukan pengguna/pengakses.

Berdasarkan observasi dalam bentuk dokumentasi toko Aneka Jaya Motor, dalam melaksanakan transaksi penjualan masih mengalami permasalahan karena masih menggunakan sistem yang bersifat konvensional, pada penjualan, karyawan harus membuat nota penjualan secara manual, memberikan informasi persediaan atau stok barang dagangan dengan melihat di etalase masih tersedia atau tidak barang yang diinginkan oleh konsumen.

Masalah yang disebutkan diatas disebabkan sistem penjualan belum tertata dengan baik, kalua hal ini masih diterapkan maka tidak relevan dengan 
tuntutan visi yang ingin dicapai, yaitu menjadi toko penyedia suku cadang mobil terbaik di Bekasi. Sehingga mengharuskan pihak toko untuk menerapkan sistem penjualan yang mampu memproses data secara cepat, akurat, dan otomatis (komputerisasi), mampu menyimpan serta menampilkan data transaksi yang berkaitan dengan sistem penjualan. Sehingga informasi yang dihasilkan lebih cepat, akurat, dan dapat terkelola dengan baik. Melihat kondisi tersebut, perlu adanya perancangan sistem informasi penjualan yang terkomputerisasi. Hal ini untuk meningkatkan keunggulan kompetitif toko dalam memberikan pelayanan yang terbaik bagi pelanggan.

Berdasarkan uraian pada latar belakang yang telah dikemukakan, maka penulis dapat merumuskan suatu permasalahan yaitu, Bagaimana Membangun E-commerce Spare Parts Mobil Pada Toko Aneka Jaya Motor. Sedangkan tujuan dari penelitian ini adalah, membangun sistem berbasis website untuk memudahkan pemilik dan pembeli Toko Aneka jaya Motor dalam melakukan transaksi jual-beli.

\section{METODE PENELITIAN}

Jenis penelitian yang digunakan adalah penelitian kualitatif dengan metode waterfall. Penelitian kualitatif merupakan penelitian tentang riset yang bersifat deskriptif dan cenderung menggunakan analisis. Proses dan makna (perspektif subyek) lebih ditonjolkan dalam penelitian kualitatif. Landasan teori dimanfaatkan sebagai pemandu agar fokus penelitian sesuai dengan fakta di lapangan. Selain itu landasan teori juga bermanfaat untuk memberikan gambaran umum tentang latar penelitian dan sebagai bahan pembahasan hasil penelitian.

\section{A. Sistem}

\section{Sistem Informasi}

Sistem Informasi adalah suatu sistem didalam suatu organisasi yang mempertemukan kebutuhan pengolahan transaksi harian yang mendukung fungsi operasi organisasi yang bersifat manajerial dengan kegiatan strategi dari suatu organisasi untuk dapat menyediakan kepada pihak luar tertentu dengan laporan-laporan yang diperlukan [1].

\section{E-Commerce}

Perdagangan elektronik (Electronic Commerce atau e-commerce) adalah penyebaran, pembelian, penjualan, pemasaran barang dan jasa melalui sistem elektronik seperti internet atau televise, $w w w$, atau jaringan computer lainnya. E-commerce dapat melibatkan transfer dana elektronik, sistem manajemen inventori otomatis, dan sistem pengumpulan data otomatis. Industri teknologi informasi melihat kegiatan e-commerce ini sebagai aplikasi dan penerapan dari e-bussiness yang berkaitan dengan transaksi komersial, seperti: transfer dana secara elektronik, SCM(Supply Chain Management), e-marketing, atau pemasaran online, pemrosesan transaksi online (online transaction processing), pertukaran data elektronik (electronic data interchange/EDI) dan lain-lain. E-commerce merupakan bagian dari e-bussiness, dimana cakupan e-bussiness lebih luas, tidak hanya sekedar perniagaan tetapi mencakup juga pengkolaborasian mitra bisnis, pelayanan nasabah, lowongan pekerjaan, dan lainlain. Penggunaan teknologi informasi ini kemudian menghasilkan hubungan bentuk batu seperti : A. $\mathrm{B} 2 \mathrm{~B}$ (Business to Business); dan B. B2C(Business to Customer); dan C. C2C(Customer to Customer).

Bahkan saat ini dengan adanya e-commerce, teknologi informasi memiliki peran yang sangat penting bagi perusahaan untuk melakukan promosi produk, sosialisasi berbagai jasa pelayanan, memberikan discount khusus, termasuk kerjasama antar mitra kerja dan pelaku bisnis, serta membuka bisnis baru di wilayah yang berpotensi. Kegiatan tersebut dapat dilakukan secara offline maupun secara online melalui situs website resmi [2].

\section{Bagan Alur Sistem (Flowchart)}

Flowchart atau diagram alir merupakan sebuah diagram dengan symbol-simbol grafis yang menyatakan aliran algoritma atau proses yang menampilkan langkah-langkah yang disimbolkan dalam bentuk kotak, beserta urutannya dengan menghubungkan masing-masing langkah tersebut menggunakan tanda panah. Diagram ini bisa memberi solusi selangkah demi selangkah untuk penyelesaian masalah yang ada didalam proses atau algoritma tersebut. Panduan membuat flowchart [3] : 1. Pahami dan cermati deskripsi naratif prosedur; dan 2. Pilih simbol flowchart standar, yang mudah digunakan dan dipahami; dan 3. Siapkan draft atau lembar kerja flowchart; dan 4. Flowchart digambarkan harus dari halaman atas ke bawah dan dari kiri ke kanan; dan 5. Aktifitas yang digambarkan harus didefinisikan secara hati-hati dan definisi ini harus dapat dimengerti oleh pembacanya; dan 6. Kapan aktifitas dimulai dan berakhir harus ditentukan secara jelas, dicerminkan dari simbol-simbol yang digunakan; dan 7. Lengkapi flowchart dengan mencantumkan judul, tanggal, dan nama yang mempersiapkan. 


\section{Pemodelan Sistem}

Unified Modelling Language (UML) adalah Bahasa pemodelan untuk sistem atau perangkat lunak yang berparadigma berorientasi objek. Pemodelan sesungguhnya digunakan untuk penyerdehanaan permasalahan-permasalahan yang kompleks sedemikian rupa sehingga lebih mudah dipelajari dan dipahami. Adapun tujuan pemodelan dalam kerangka pengembangan sistem atau perangkat lunak aplikasi yaitu sebagai sarana analisis, pemahaman, visualisasi, dan komunikasi antar anggota tim pengembang saat seorang analisis atau perancang perangkat lunak secara seksama serta bermanfaat untuk melakukan pengujian terhadap perangkat lunak yang telah selesai dikembangkan [4].

\section{B. Penelitian Terdahulu}

Ardi Widayanto dan Indah Uly Wardati dengan judul Perancangan Sistem Informasi Penjualan Spare Parts Mobil Pada Bengkel Samsi Motor Pacitan, dengan hasil penelitian tersebut adalah, pada pengolahan data pembelian serta penjualan bengkel Samsi dicatat pada buku besar, hal ini membuat tidak efisiennya pengolahan pembelian dan penjualan serta sering muncul hilangnya faktur penjualan yang merupakan bukti dari transaksi yang dilakukan [5].

Choirul Mualifah, Bambang Eka Purnama dan Sukadi dengan judul Sistem Informasi Penjualan Barang Pada Bengkel Karunia Motor Arjosari, dengan hasil penelitian tersebut adalah, pengelolaan data secara konvensional belum dapat menjamin kebenaran informasi yang diberikan karena data yang dihasilkan secara konvensional presentase kesalahan manusia lebih besar dibandingkan dengan hasil yang dihasilkan secara komputerisasi. Bahasa pemrograman yang digunakan dalam penelitian ini adalah PHP [6].

Nugraha Setiadi dan Ridwan Setiawan dengan judul Pengembangan Aplikasi Penjualan Sparepart di Bengkel Anugrah Jaya Motor Berbasis Desktop, dengan hasil penelitian tersebut adalah, dalam penelitian ini yang digunakan adalah UML sebagai pemodelannya. Hasil dari penelitian ini adalah perancangan aplikasi penjualan berbasis desktop [7].

Sandy Kosasi dengan judul Perancangan Sistem E-commerce Untuk Memperluas Pasar Produk Oleh-Oleh Khas Pontianak, dengan hasil penelitian tersebut adalah, perancangan sistem e-commerce khusus produk oleh-oleh khas Pontianak memiliki fasilitas untuk menyimpan data pribadi member (anggota) dengan dilengkapi dengan username dan password untuk mengantisipasi penyalahgunaan oleh orang-orang yang tidak bertanggung jawab. Sistem e-commerce ini juga menyediakan fasilitas pembayaran melalui transfer bank dan cash on delivery, selain itu memiliki fitur menarik seperti ajak teman, dan pemberian hadiah berupa voucher diskon belanja saat anggota ulang tahun. Arsitektur aplikasi ini juga dapat digunakan untuk memasukkan data baru dan mengubah data yang sudah ada serta dapat memberikan informasi data pembelian yang dilakukan anggota kepada pemilik toko [8].

Abdul Ghaffar Khan dengan judul Electronic Commerce: A Study on Benefits and Challenges in an Emerging Economy, dengan hasil penelitian tersebut adalah, industri e-commerce akan menjadi pemimpin dengan popularitas di dunia bisnis elektronik di tahun-tahun mendatang. Revolusi e-commerce telah mengubah bisnis transaksi secara fundamental dengana memberikan peluang baru dan dengan mudah melanggar batas [9].

Berdasarkan penelitian terdahulu yang telah disebutkan, metode yang digunakan peneliti adalah metode waterfall. Dikarenakan pada penelitian terdahulu metode ini digunakan dan menurut peneliti metode ini cocok untuk penelitian ini. Peneliti juga menggunakan UML berdasarkan penelitian terdahulu, agar kebutuhan sistem dapat dijabarkan dengan jelas.

\section{Metode Pengembangan Sistem}

Pada penelitian ini, metode pengembangan sistem yang digunakan adalah waterfall yang merupakan salah satu metode dalam System Development Life Cycle (SDLC) yang mempunyai ciri khas pengerjaan setiap fase dalam waterfall harus diselesaikan terlebih dahulu sebelum melanjutkan ke fase selanjutnya. Metode waterfall adalah pengerjaan dari suatu sistem dilakukan secara beruntun atau secara linear. Tahapan waterfall dapat dilihat pada Gambar 1

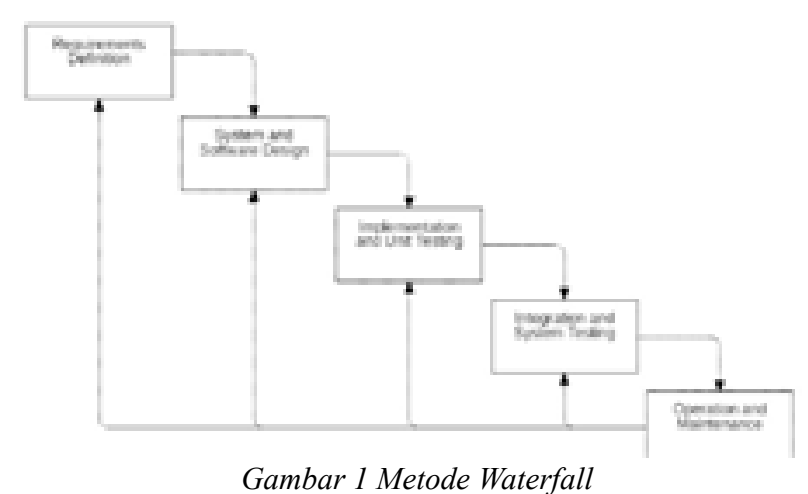

Tahapan dari metode waterfall adalah sebagai berikut: 1) requirements Definition, seluruh 
kebutuhan software harus bisa didapatkan dalam fase ini, termasuk didalamnya kegunaan software yang diharapkan pengguna dan batasan software; dan 2) System and Software Design, tahap ini dilakukan sebelum melakukan coding. Tahap ini bertujuan untuk memberikan gambaran apa yang seharusnya dikerjakan dan bagaiman tampilannya; dan 3. Implementation and Unit Testing, dalam tahap ini dilakukan pemrograman pembuatan software dipecah menjadi modul-modul kecil yang nantinya akan digabungkan dalam tahap berikutnya; dan 4 . Integration and System Testing, ditahap ini dilakukan penggabungan modul-modul yang sudah dibuat dan dilakukan pengujian, ini dilakukan untuk mengetahui apakah software yang dibuat telah sesuai dengan desainnya dan masih terdapat kesalahan atau tidak; dan 5. Operation and Maintenance, ini merupakan tahap terakhir dalam model waterfall. Software yang sudah jadi dijalankan serta dilakukan pemeliharaan. Pemeliharaan termasuk dalam memperbaiki kesalahan yang tidak ditemukan pada langkah sebelumnya.

\section{Metode Pengujian Sistem}

Pengujian aplikasis e-commerce untuk toko Aneka Jaya Motor berbasis website ini, peneliti melakukan uji coba menggunakan Black Box testing ini. Pengujian black box dilakukan pada enduser. Pada pengujian black box testing ini, peneliti melakukan pengujian fungsional dari setiap halaman menu yang ada pada aplikasi e-commerce Aneka Jaya Motor.

\section{E. Kerangka Berpikir}

Kerangka berpikir disusun berdasarkan tinjauan pustaka dan contoh hasil penelitian yang relevan atau terkait. Kerangka berpikir ini sebagai suatu argumentasi kita dalam merumuskan hipotesis. Dalam merumuskan suatu hipotesis tersebut, argumentasi kerangka berpikir menggunakan logika deduktif dengan memakai pengetahuan ilmiah sebagai premispremis dasarnya.

Kerangka berpikir digambarkan dalam bentuk diagram yang menjelaskan secara garis besar alur logika berjalannya penelitian. Kerangka berpikir dibuat berdasarkan representasi suatu konsep. Peneliti menjelaskan rangkaian proses penelitian yang dilakukan dalam kerangka berpikir sesuai dengan Gambar 2.

Berdasarkan Gambar 2, maka dapat dijelaskan tahap aktifitas penelitian sebagai berikut: 1) Pada awal penelitian, peneliti merumuskan masalah yang terjadi dan melakukan pengumpulan studi literature

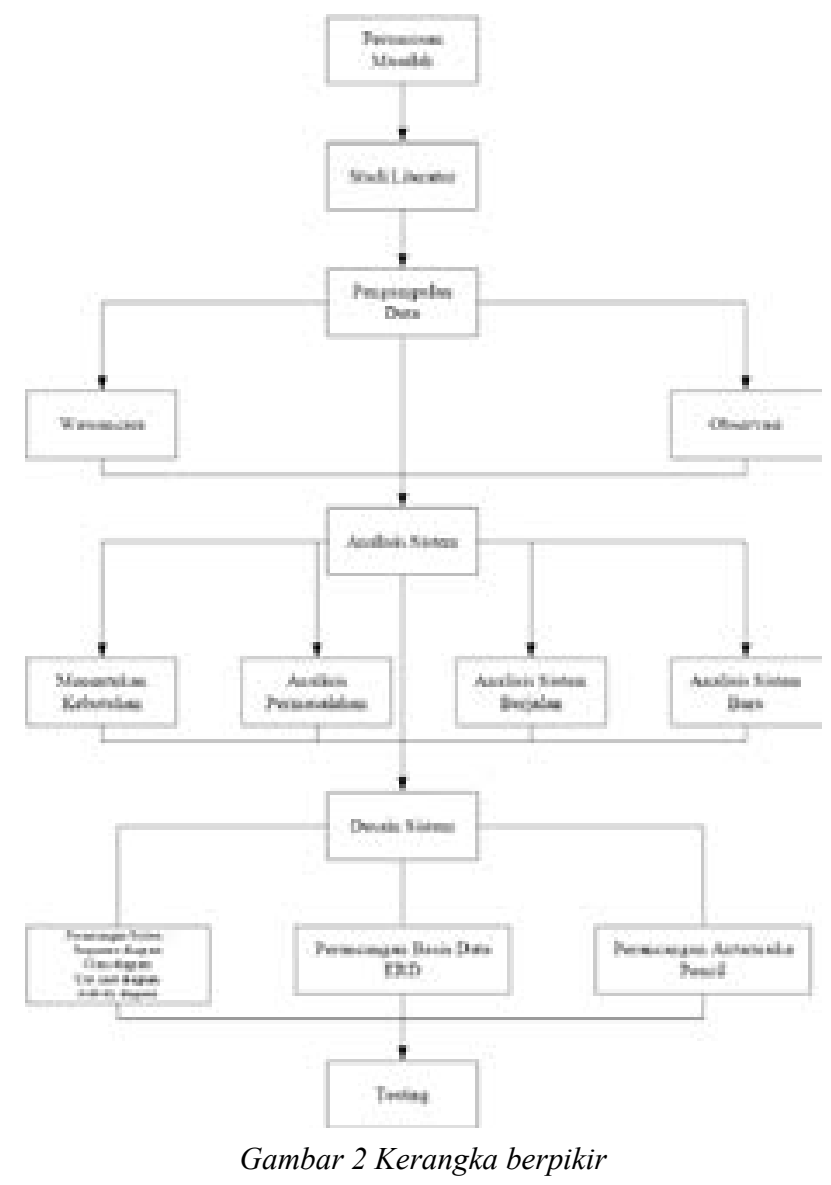

mengenai penelitian terdahulu, mengumpulkan data dengan cara mengumpulan jurnal, paper, dokumen dan buku yang berkaitan dengan penelitian data. Pengumpulan data dilakukan melalui dua langkah, yaitu: a) Wawancara mengenai permasalahan sistem yang digunakan saat ini, kendala yang dihadapi dan kebutuhan pembuatan sistem baru yang akan dibuat; dan b) Observasi dengan pengamatan langsung mengenai permasalahan sistem yang digunakan saat ini. Selanjutya, peneliti menganalisis sistem berjalan untuk mengidentifikasi kendala yang dihadapi dan memberikan sistem usulan dengan menggunakan UML untuk pemodelannya; 2) Pada tahap kedua, peneliti melakukan perancangan sistem, perancangan sistem dilakukan dalam empat langkah, yaitu:A. Pemodelan sistem menggunakan pemodelan berorientasi objek dengan membuat use case diagram, activity diagram, sequence diagram dan class diagram; dan B. Perancangan basis data digambarkan dalam bentuk model lain; 3) Tahap ketiga adalah pengembangan sistem, pengembangan sistem dilakukan tiga langkah, yaitu:A. Pembuatan basis data menggunakan ERD; dan B. Pemrograman sistem dengan bahasa pemrograman PHP menggunakan software Notepad++; 4) Pada tahap keempat, peneliti menguji sistem yang telah dibuat menggunakan pengujian black box. Peneliti melakukan pengujian fungsional dari setiap halaman menu yang ada pada 
website e-commerce toko Aneka Jaya Motor; dan 5) Jika tahap-tahap tersebut telah selesai, dilakukan dan sesuai dengan persyaratan pengguna, maka sistem baru akan diterapkan. Peneliti juga dapat membuat simpulan dan saran dari penelitian yang telah dibuat.

\section{HASIL DAN PEMBAHASAN}

\section{A. Analisis Sistem}

Analisa sistem yang akan dibuat bertujuan untuk mengetahui lebih jelas bagaiman cara kerja sistem tersebut dan masalah yang dihadapi untuk dapat dijadikan landasan usulan perancangan analisa sistem yang sedang berjalan. Dengan adanya analisa maka akan didapatkan suatu gambaran tentang alat dan materi yang dibutuhkan dalam pembuatan e-commerce pada Toko Aneka Jaya Motor. Aneka Jaya Motor merupakan suatu perusahaan yang bergerak dalam bidang usaha penjualan spare part mobil di Kota Bekasi. Dengan sistem yang sedang berjalan terdapat banyak kekurangan dan masalah diantaranya dalam pemasarannya masih manual, yaitu pembeli harus datang langsung ke toko Aneka Jaya Motor untuk memilih barang yang ingin dibelinya.

\section{B. Perancangan Sistem}

Dalam perancangan sistem baru menggunakan pemodelan yang digambarkan dengan use case

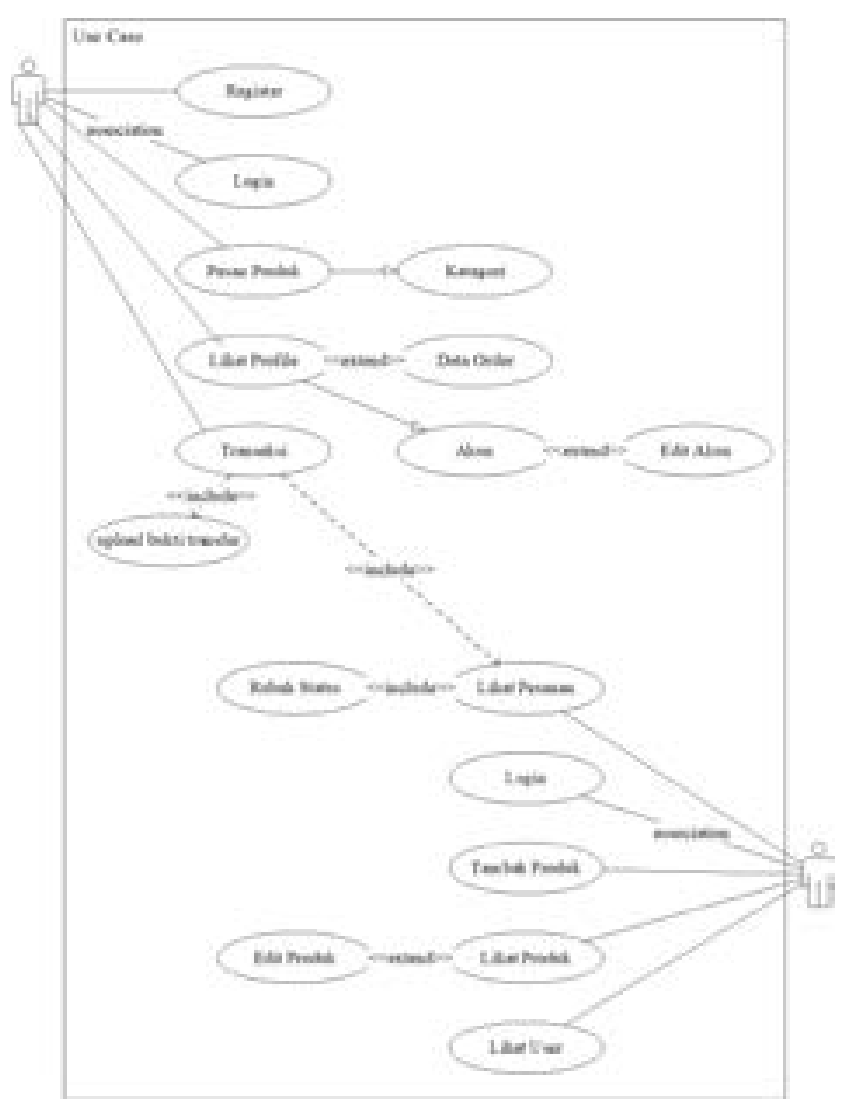

Gambar 3 Use case diagram diagram, class diagram, sequence diagram, dan activity diagram serta peracangan basis data dengan ERD.

\section{Use Case Diagram}

Berdasarkan Gambar 3, e-commerce spare parts mobil pada toko Aneka Jaya Motor terdiri dari dua actor yaitu user dan admin. User dapat melakukan registrasi kemudian dapat melakukan login, setelah melakukan login user dapat melakukan pembelian produk, di menu akun pengguna dapat melihat data order dan mengedit profile data pengguna dan mengkonfirmasi pesanan kepada admin Aneka Jaya Motor. Admin dapat registrasi login dan logout akun kemudian mengelola daftar pesanan maupun melihat daftar akun user dan admin dapat menambahkan produk hingga edit produk.

\section{Activity Diagram}

Activity Diagram menggambarkan rangkaian aliran dari aktivitas yang dapat digunakan untuk mendeskripsikan aktivitas yang di bentuk dalam suatu operasi sehingga dapat digunakan untuk aktivitas yang lain seperti use case, aktivitas merupakan bentuk khusus dari keadaan dimana aktivitas menggambarkan kegiatan yang dilakukan.

\section{Activity Diagram Register}

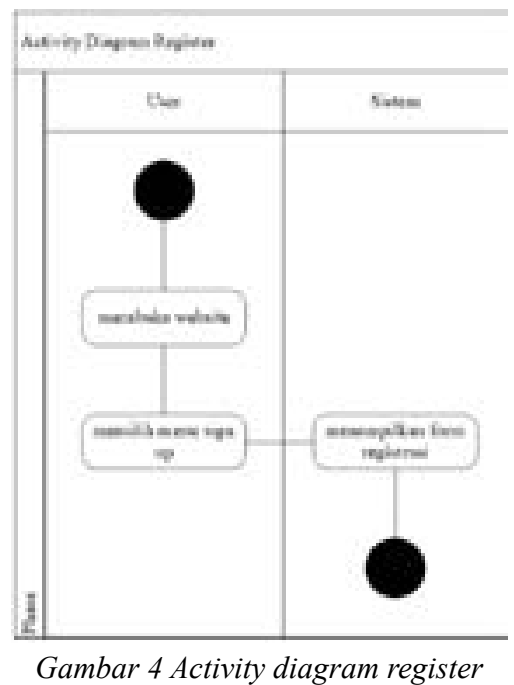

Pada Gambar 4 dijelaskan bahwa activity diagram register ini ketika user memulai dari membuka website lalu user memilih menu sign up dan sistem menampilkan form registrasi yang harus diisi oleh user.

\section{Activity Diagram Login}

Pada Gambar 5 dijelaskan bahwa activity diagram login ini ketika user memulai dari membuka website, kemudian user memilih menu login, setelah 


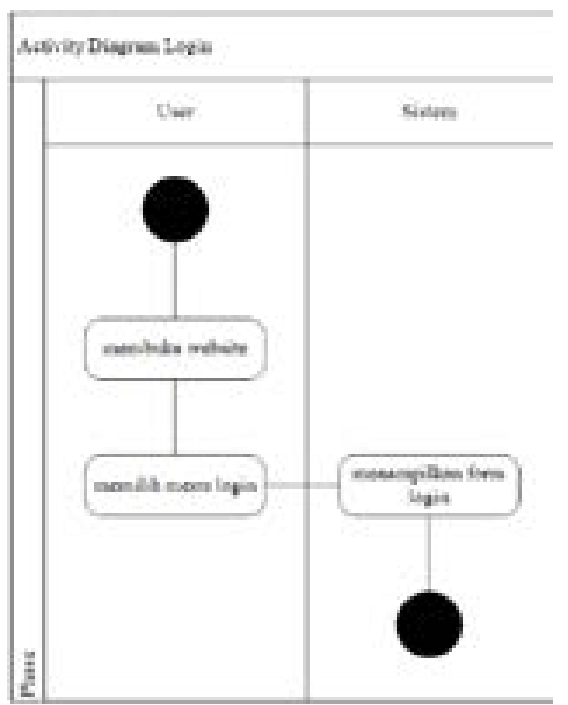

Gambar 5 Activity diagram login

user mengklik menu login, user dapat melakukan pengisian form pada tampilan login kemudian user dapat melakukan login.

\section{Activity Diagram Pesan Produk}

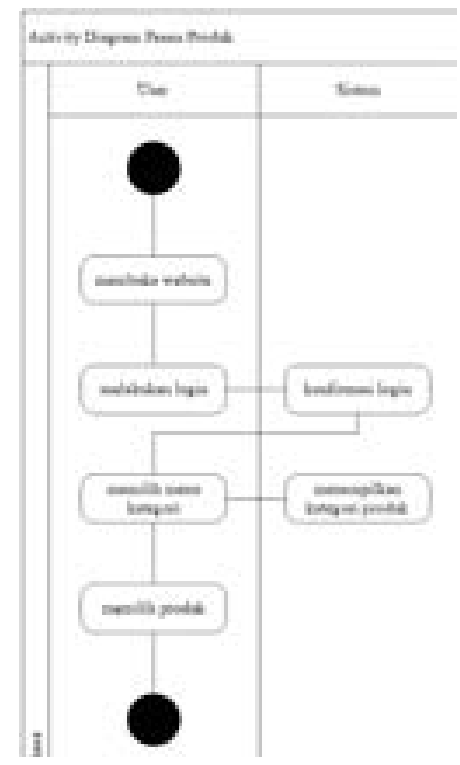

Gambar 6 Activity diagram pesan produk

Pada Gambar 6 dijelaskan bahwa user memulai dari membuka website, kemudian user memilih menu login, setelah login, user dapat memilih menu kategori untuk melihat dan memesan produk.

\section{Activity Diagram Lihat Profile}

Pada Gambar 7 dijelaskan bahwa user memulai dari membuka website dan melakukan login, setelah login kemudian user dapat memilih menu profil, di dalam menu profil terdapat detail profil, edit profil, dan riwayat transaksi.

\section{Activity Diagram Login Admin}

Pada Gambar 8 dijelaskan bahwa admin memulai dari membuka website, kemudian admin

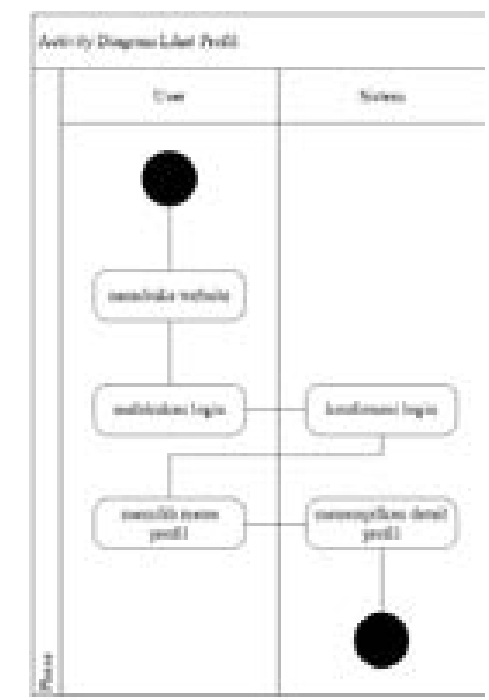

Gambar 7 Activity diagram lihat profile

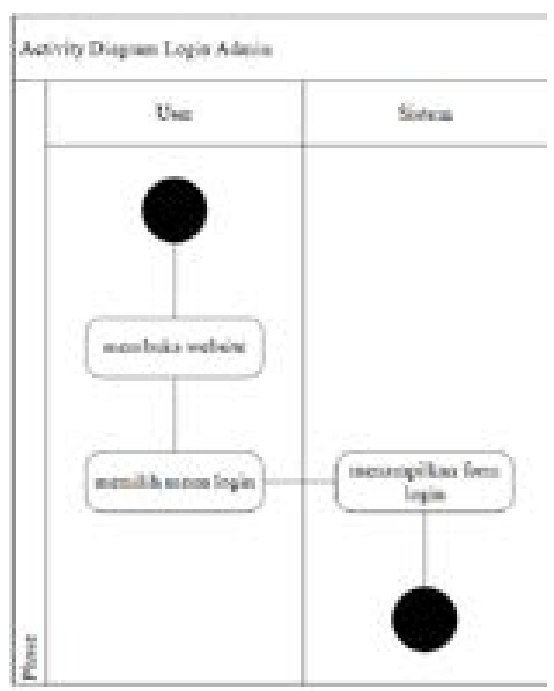

Gambar 8 Activity diagram login admin memilih menu login, setelah itu admin dapat mengisi form login yang tersedia.

\section{Activity Diagram Lihat Pesanan}

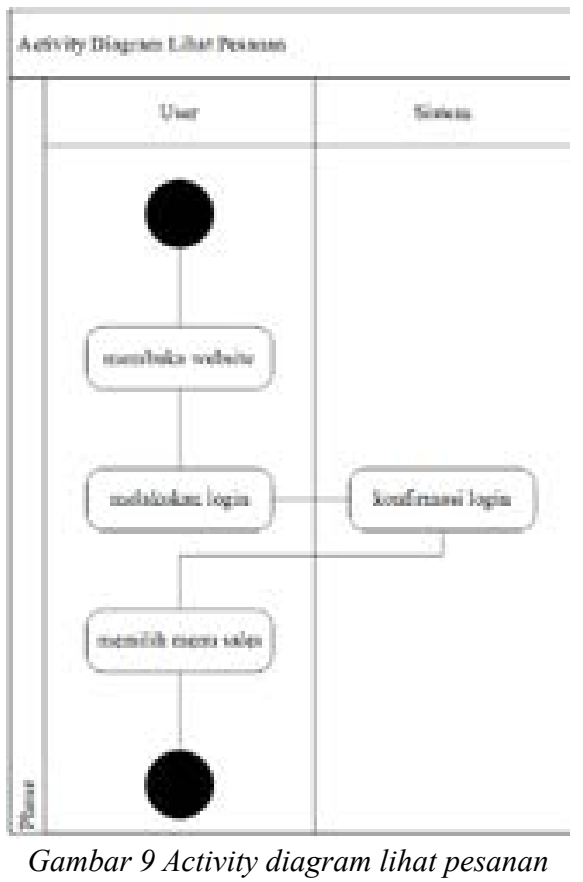


Pada Gambar 9 dijelaskan bahwa ketika admin sudah melakukan login, admin hanya perlu memilih menu sales untuk dapat melihat pesanan.

\section{Activity Diagram Tambah Produk}

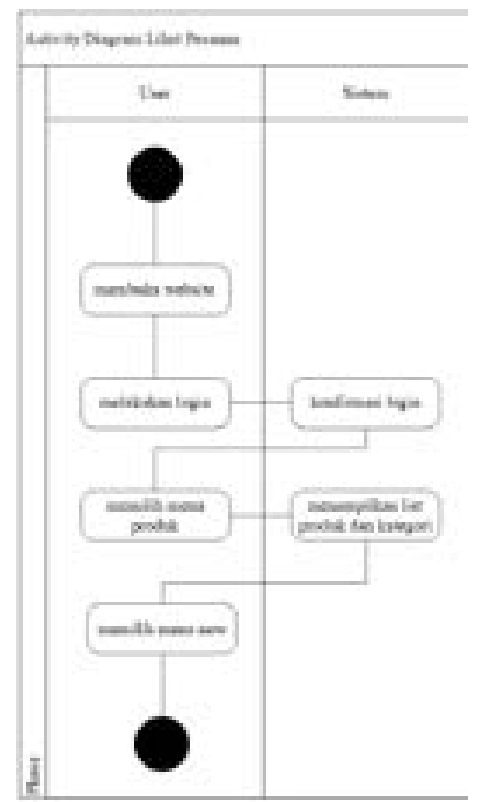

Gambar 10 Activity diagram tambah produk

Pada Gambar 10 dijelaskan bahwa ketika admin sudah melakukan login, admin memilih menu produk, lalu sistem akan menampilkan produk list dan kategori, lalu admin memilih menu new untuk menambah produk.

\section{Activity Diagram Lihat Produk}

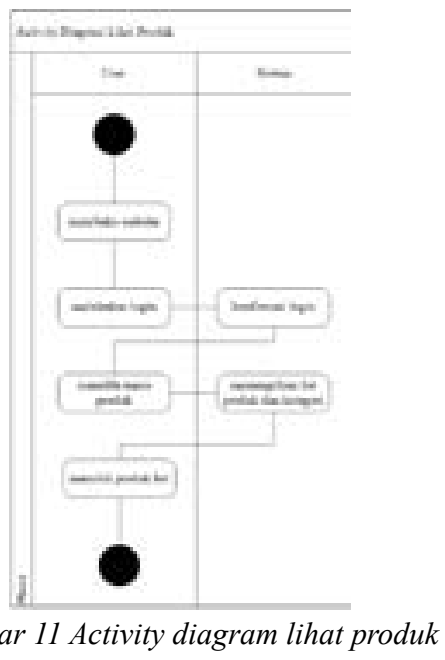

Pada Gambar 11 dijelaskan bahwa ketika admin sudah melakukan login admin dapat memilih menu produk dan klik menu produk list untuk melihat produk.

\section{Activity Diagram Lihat User}

Pada Gambar 12 dijelaskan bahwa setelah admin login, admin langsung dapat melihat user di menu lihat user.

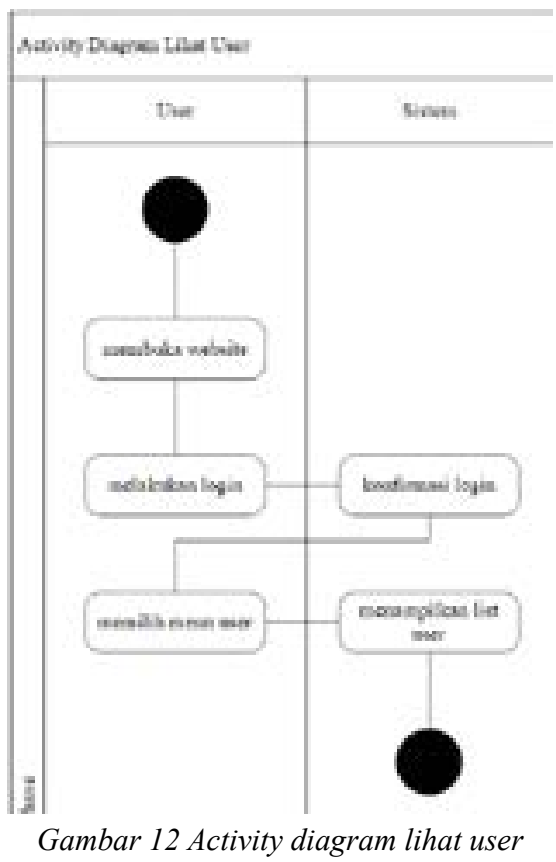

\section{Sequence Diagram}

Sequence Diagram dari e-commerce spare parts mobil di Aneka Jaya Motor adalah sebagai berikut :

\section{Sequence Diagram Register}

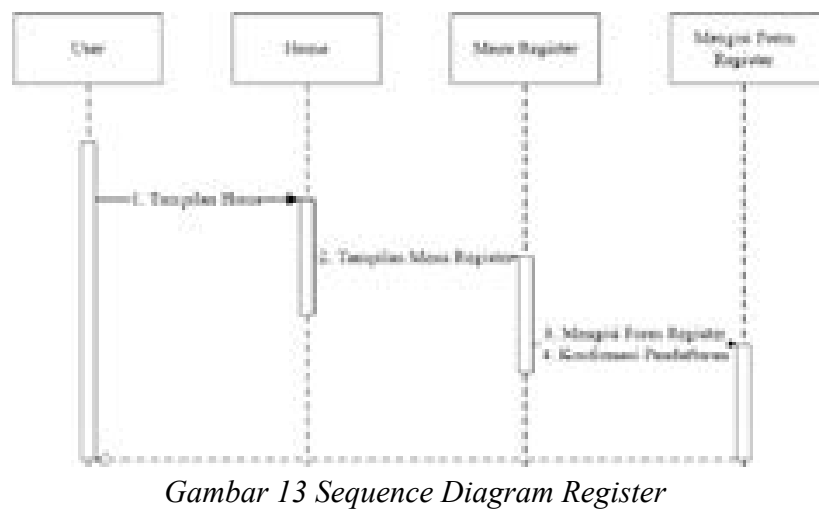

Gambar 13 menjelaskan sequence diagram register, ketika user ingin melakukan pendaftaran akun, user memulai dengan masuk ke menu tampilan home kemudian user masuk ke tampilan register, setelah masuk di menu register user langsung melakukan pengisian form register dan mengkonfirmasi pendaftaran akun.

\section{Sequence Diagram Login}

Gambar 14 menjelaskan sequence diagram login, ketika user ingin login akun user memulai dengan masuk ke menu tampilan home kemudian konsumen masuk ke tampilan login, setelah masuk di menu login konsumen langsung mengisi form login dan mengkonfirmasi untuk dapat login.

\section{Sequence Diagram Pesan Produk}

Gambar 15 menjelaskan sequence diagram pesan produk, dimulai dari tampilan awal lalu user 


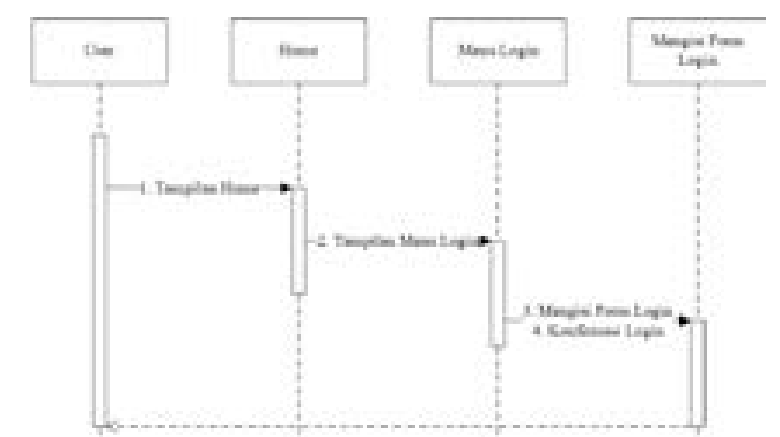

Gambar 14 Sequence diagram login

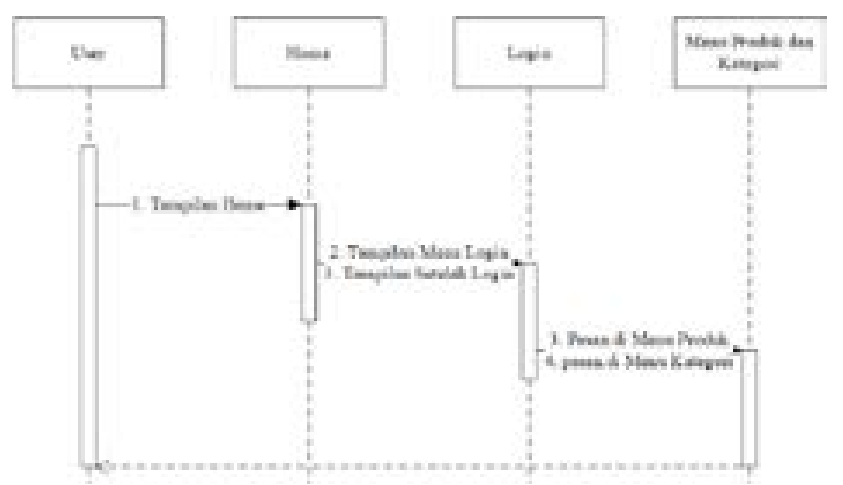

Gambar 15 Sequence diagram pesan produk

melakukan login akun dan user akan dapat langsung memilih produk dengan menu produk yang akan menampilkan semua produk di Aneka Jaya Motor dan bisa memilih produk dengan menu kategori yang akan menampilkan spare parts.

\section{Sequence Diagram Lihat Profile}

Gambar 16 menjelaskan sequence diagram lihat profile, dimulai dari tampilan awal lalu user melakukan login akun, kemudian user langsung dapat melihat menu lihat profile, di dalam menu lihat profile, user dapat melihat data order dan dapat mengedit data akun.

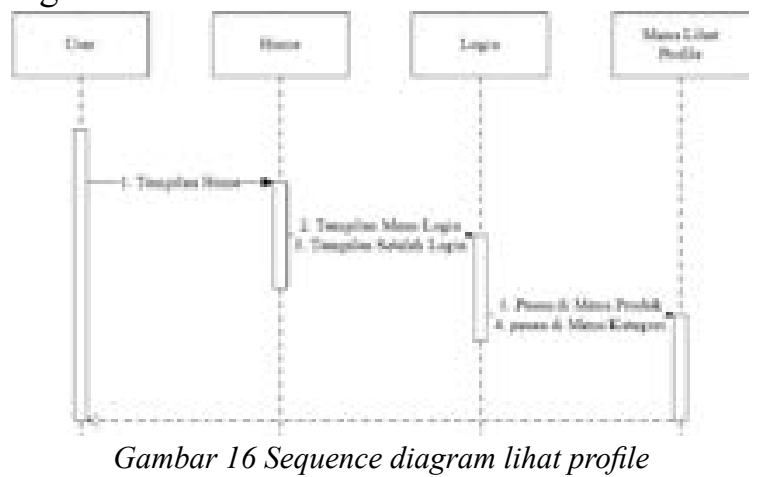

\section{Sequence Diagram Login Admin}

Gambar 17 menjelaskan sequence diagram login admin, di halaman ini admin hanya memasukkan id dan password, dan untuk dapat masuk admin harus mengkonfirmasi login.

\section{Sequence Diagram Lihat Pesanan}

Gambar 18 menjelaskan sequence diagram lihat pesanan, saat admin sudah melakukan login dan

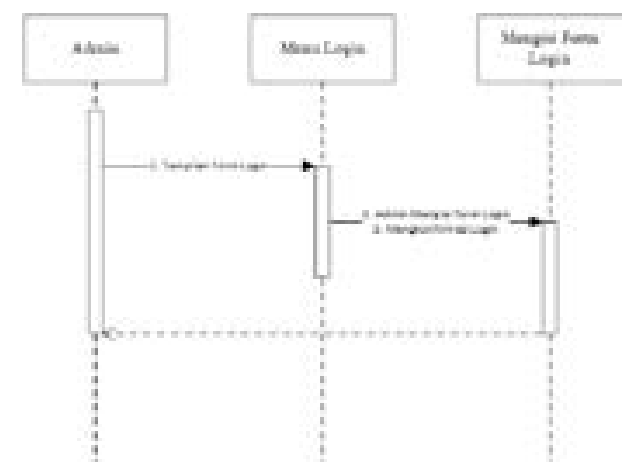

Gambar 17 Sequence diagram login admin

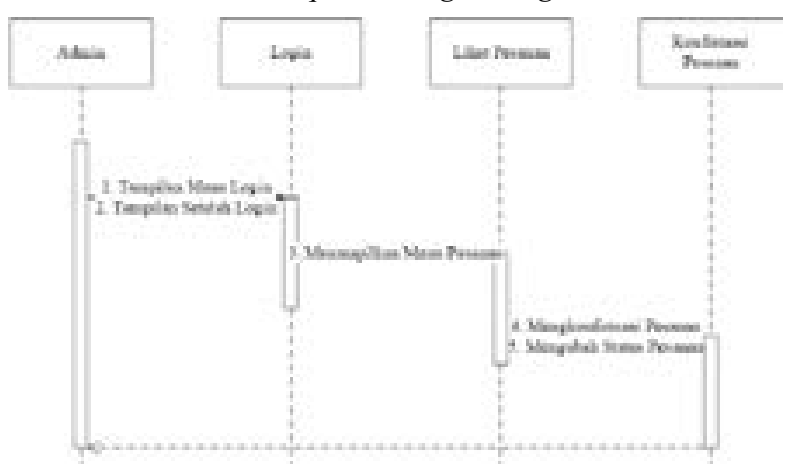

Gambar 18 Sequence diagram lihat pesanan

memilih menu lihat pesanan, selanjutnya admin akan masuk di menu lihat pesanan, di menu lihat pesanan ini admin dapat melihat pesanan dari user dan dapat mengubah status barang pengiriman jika konsumen belum mengupload bukti transfer maka status barang masih pending, jika konsumen sudah mengupload bukti transfer maka status barang akan dirubah menjadi terkirim.

\section{Sequence Diagram Tambah Produk}

Gambar 19 menjelaskan sequence diagram tambah produk, saat admin melakukan login dan memilih menu tambah produk, selanjutnya admin masuk ke menu tambah produk kemudian mengisi detail produk dan upload gambar untuk menambahkan produk admin harus menyimpan produk.

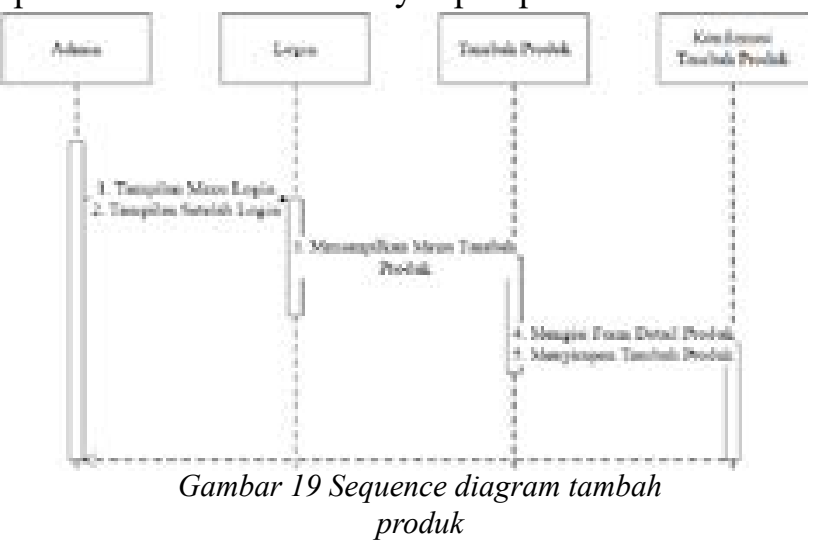

\section{Sequence Diagram Lihat User}

Gambar 20 menjelaskan sequence diagram lihat user, saat admin sudah melakukan login dan memilih menu lihat user selanjutnya admin akan masuk menu 


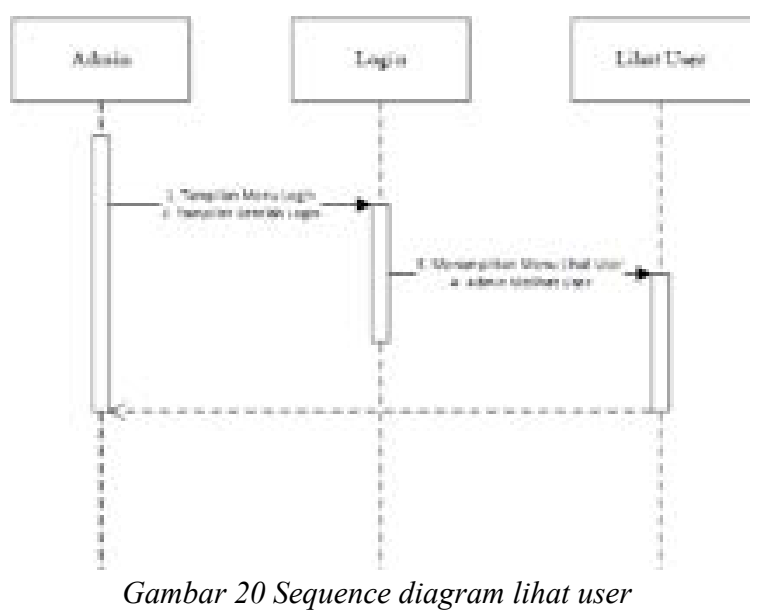

lihat user kemudian admin dapat melihat semua user Aneka Jaya Motor.

\section{Class Diagram}

Class Diagram menggambarkan struktur sistem dalam bentuk kelas-kelas yang akan dibuat dalam pengembangan aplikasi. Class diagram dari e-commerce spare parts di Aneka Jaya Motor dapat dilihat pada Gambar 21.

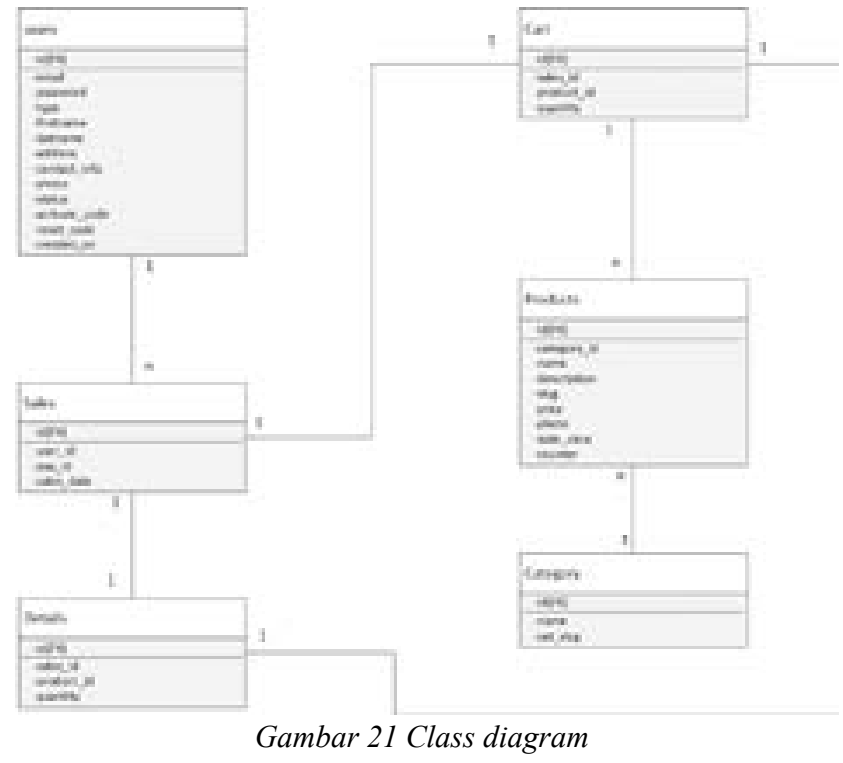

\section{Entity Relationship Diagram}

Berdasarkan Gambar 22, satu pembeli dapat membeli banyak produk, dan banyak produk terjual akan masuk ke satu laporan penjualan, di dalam satu laporan penjualan, barang yang terjual memiliki satu detail penjualan. Di dalam satu kategori memiliki banyak produk, setiap pembeli juga mendapatkan/ memiliki satu keranjang belanja.

\section{Desain Antarmuka}

\section{Desain Antarmuka Register}

Berdasarkan Gambar 23, desain antarmuka registrasi user berisi textfield yang berguna untuk

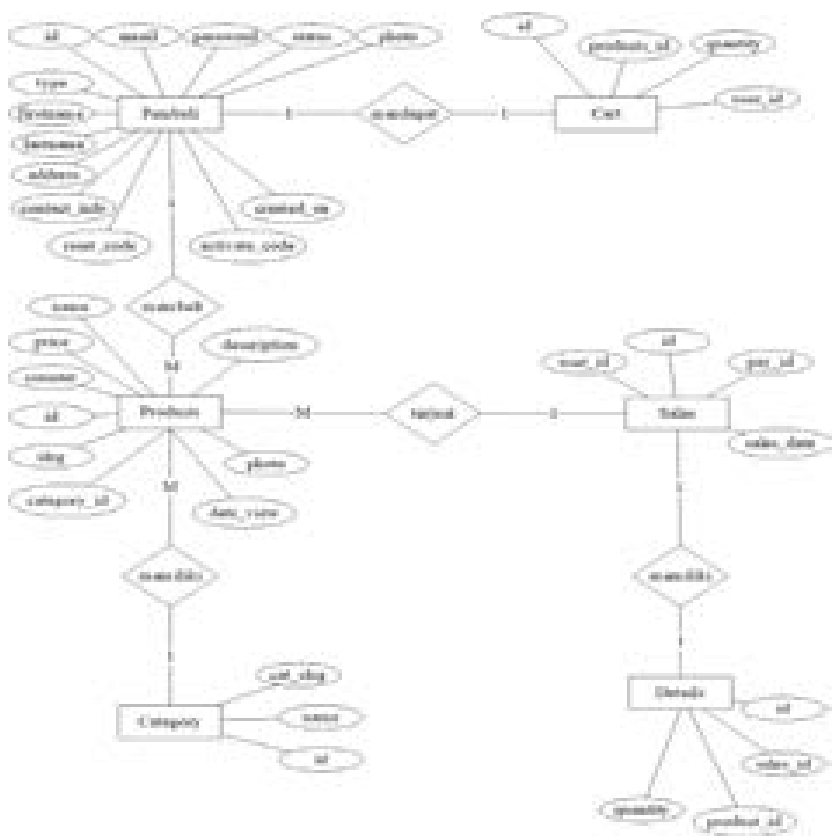

Gambar 22 Entity relationship diagram

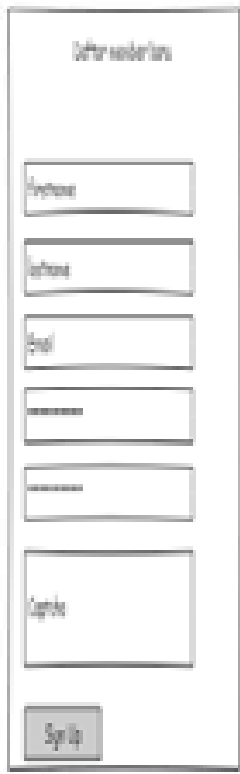

Gambar 23 Desain registrasi user

memasukkan data-data user yang diperlukan untuk keperluan registrasi. Tersedia juga kolom captcha untuk melakukan verifikasi bahwa user bukan robot.

\section{Desain Antarmuka Login}

Berdasarkan Gambar 24, desain antarmuka login berisi data email dan password yang telah user masukan saat proses registrasi. Selanjutnya user mengklik button sign in untuk melakukan proses login.

\section{Desain Antarmuka Menu Home}

Berdasarkan Gambar 25, desain antarmuka home memiliki beberapa bagian, seperti menubar sebagai navaigasi untuk user, banner, sidebar, konten yang berisi penjualan terlaris, dan footer. 


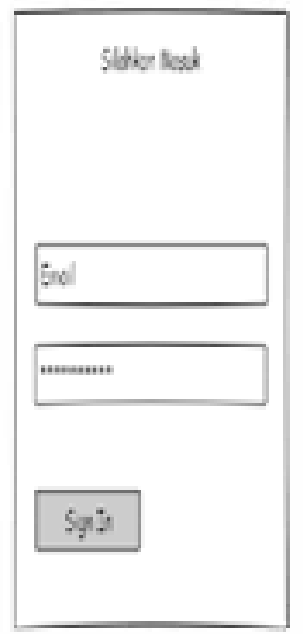

Gambar 24 Desain login

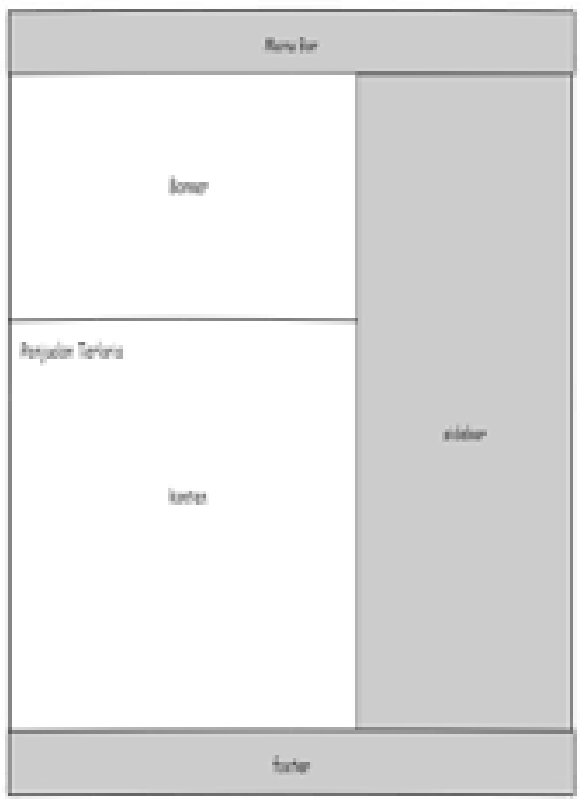

Gambar 25 Desain antarmuka home

\section{Desain Antarmuka Menu Tentang Kami}

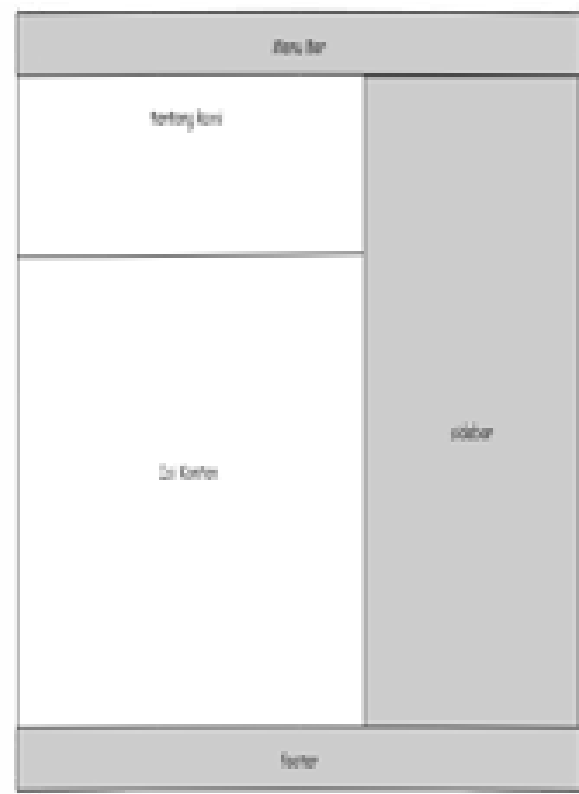

Gambar 26 Desain antarmuka tentang kami

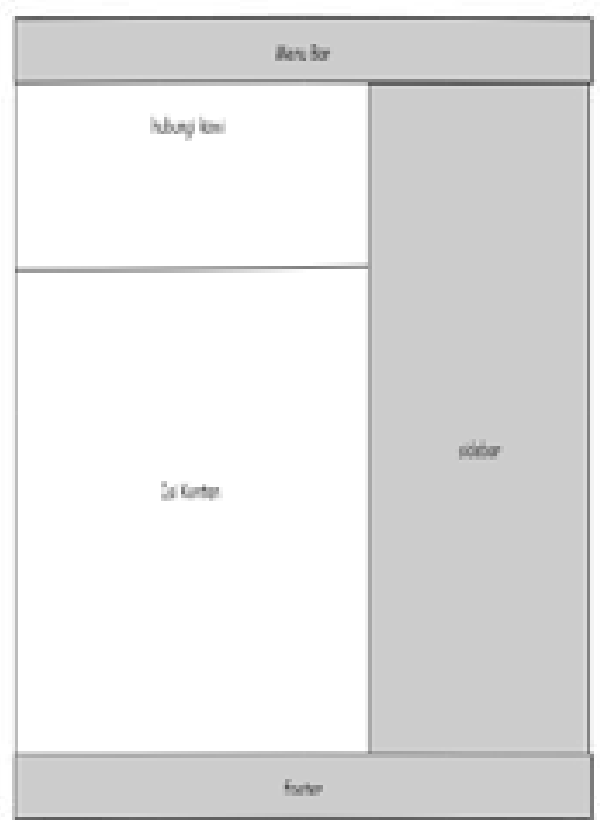

Gambar 27 Desain antarmuka hubungi kami

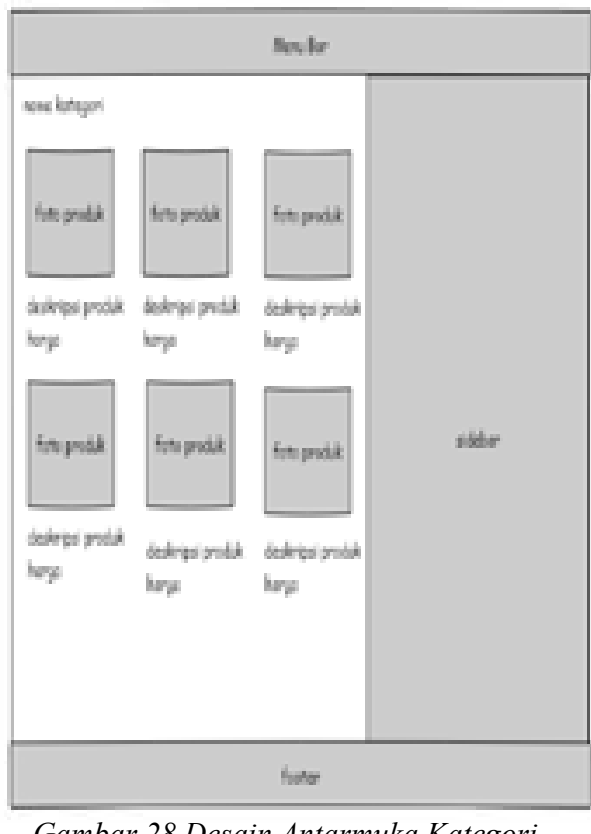

Gambar 28 Desain Antarmuka Kategori

Berdasarkan Gambar 26, desain antarmuka menu Tentang Kami tidak berbeda jauh seperti menu home, hanya memiliki perbedaan pada isi konten yang berisikan profil dari toko Aneka Jaya Motor.

\section{Desain Antarmuka Menu Hubungi Kami}

Berdasarkan Gambar 27, desain antarmuka Hubungi Kami tidak berbeda jauh dengan menu home dan tentang kami, di menu ini, berisi alamat, dan nomor telepon dari Aneka Jaya Motor.

\section{Desain Antarmuka Menu Kategori}

Berdasarkan Gambar 28, desain antarmuka menu kategori berisikan list produk produk yang dijual oleh Aneka Jaya Motor dan di sortir berdasarkan merk mobil. 


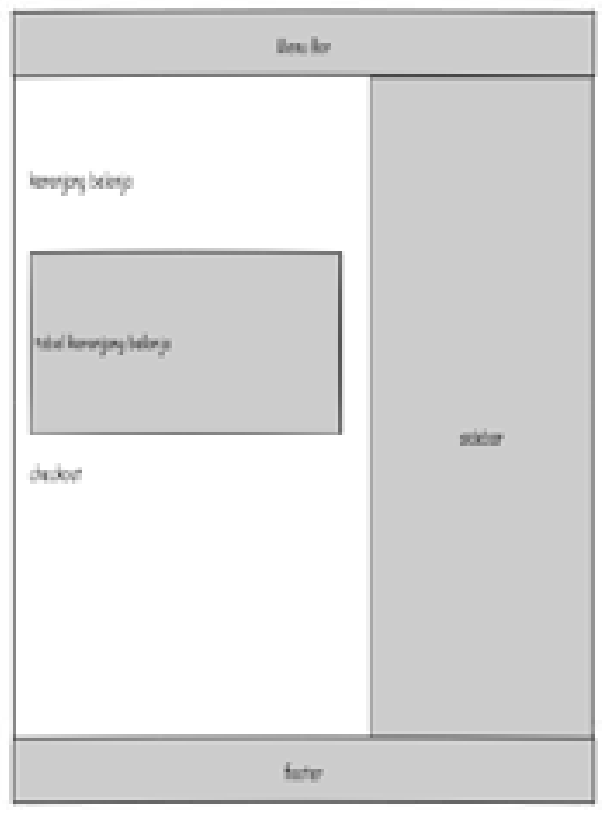

Gambar 29 Desain antarmuka keranjang belanja

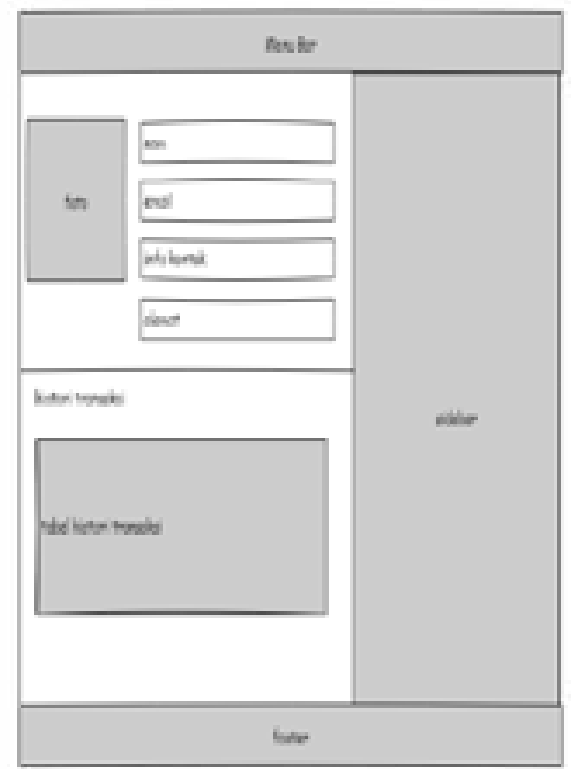

Gambar 30 Desain antarmuka profil user

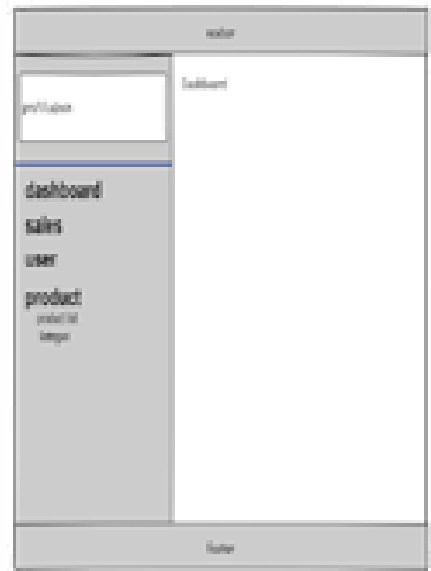

Gambar 31 Desain antarmuka dashboard admin

\section{Desain Antarmuka Menu Keranjang Belanja}

Berdasarkan Gambar 29, desain antarmuka menu keranjang belanja berisi tentang barang yang ingin dibeli oleh user dan akan ditampilan dengan bentuk tabel.

\section{Desain Antarmuka Profil User}

Berdasarkan Gambar 30, desain antarmuka menu profil berisi tentang detail profil dari user, dan riwayat transaksi user, user juga dapat mengedit data diri pada bagian ini.

\section{Desain Antarmuka Dashboard Admin}

Berdasarkan Gambar 31, desain antarmuka menu dashboard admin berisikan profil admin yang sedang online, dan beberapa menu seperti sales, user, dan product.

\section{Antarmuka pada Website}

\section{Antarmuka Register}

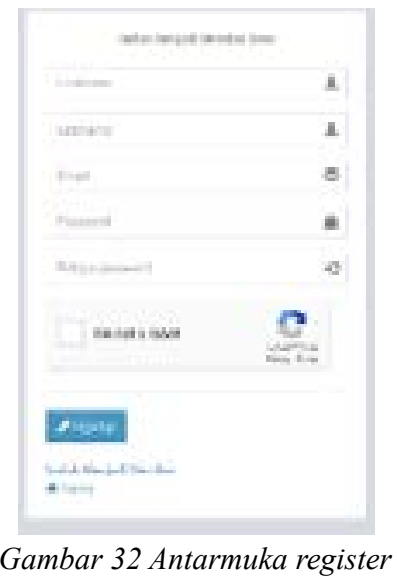

Berdasarkan Gambar 32, setiap user yang ingin menjadi member harus mengisi data-data yang diperlukan pada textfield yang sudah disediakan.

\section{Antarmuka Login}

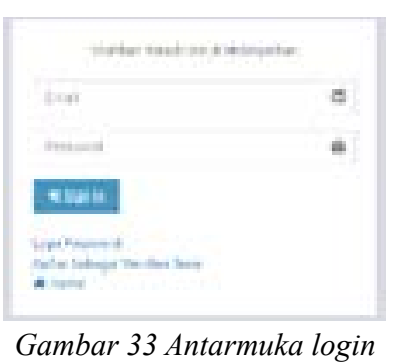

Berdasarkan Gambar 33, user yang ingin melakukan login harus mengisi form yang telah disediakan, yaitu email dan password, terdapat juga fitur lupa password dan home untuk kembali ke menu awal.

\section{Antarmuka Menu Home}

Berdasarkan Gambar 34, Tampilan home berisi menubar pada bagian atas dan konten berada di tengah serta sidebar di sebelah kanan. 


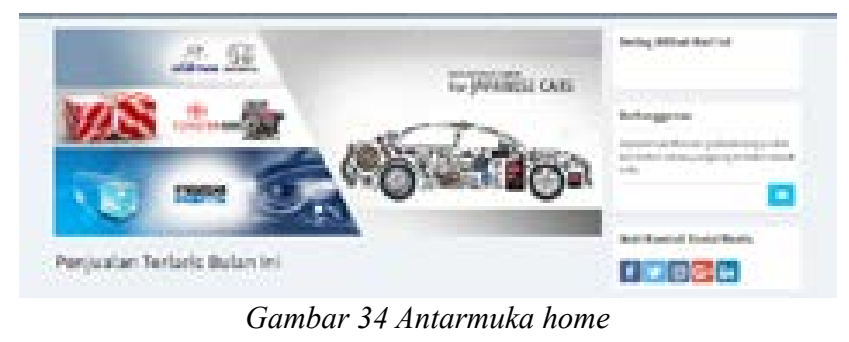

4. Antarmuka Menu Tentang Kami

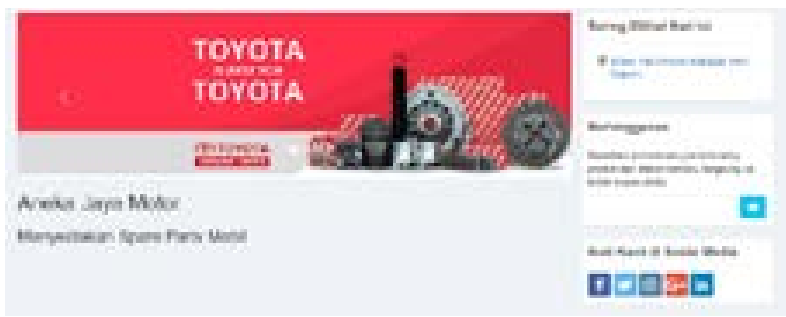

Gambar 35 Antarmuka tentang kami

Berdasarkan Gambar 35 menunjukkan antarmuka tentang kami yang berisi informasi mengenai Aneka Jaya Motor.

\section{Antarmuka Hubungi Kami}

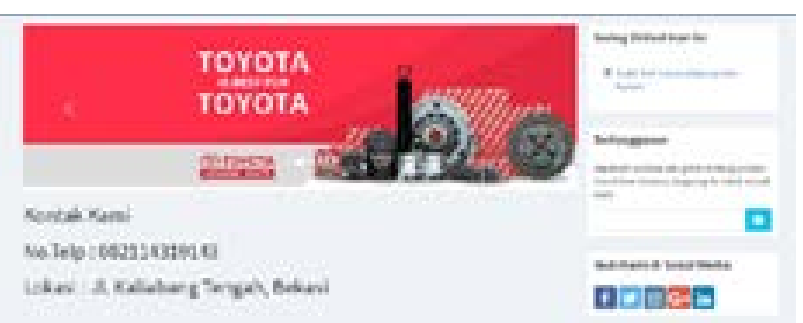

Gambar 36 Antarmuka hubungi kami

Berdasarkan Gambar 36, antarmuka menu hubungi kami menunjukkan kontak dari toko dan lokasi toko.

\section{Antarmuka Kategori Produk}

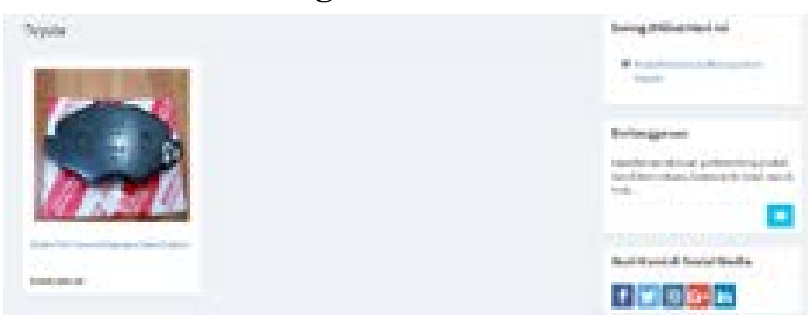

Gambar 37 Antarmuka kategori produk

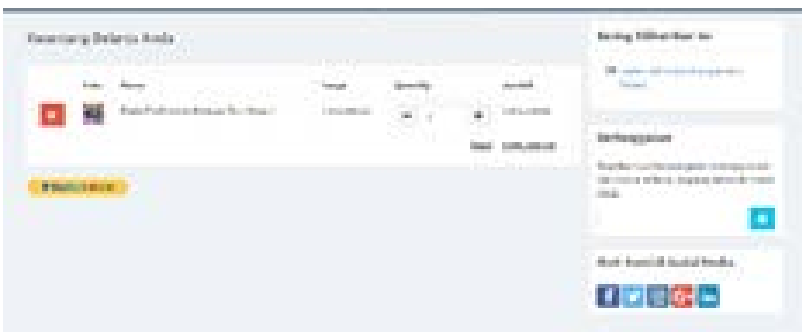

Gambar 38 Antarmuka keranjang belanja
Berdasarkan Gambar 37, isi dari antarmuka menu kategori produk adalah list produk yang nantinya dapat di update oleh admin.

\section{Antarmuka Keranjang Belanja}

Berdasarkan Gambar 38, antarmuka menu keranjang berisi daftar barang yang sudah dipilih user.

\section{Antarmuka Profil User}

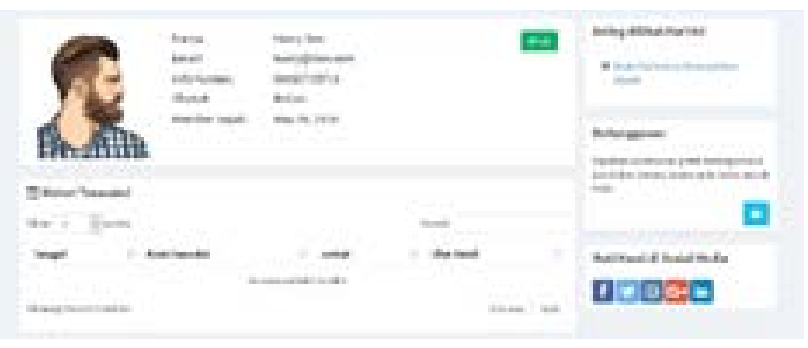

Gambar 39 Antarmuka profil user

Berdasarkan Gambar 39, tampilan profile user berisi data user dan riwayat transaksi user.

\section{Antarmuka Dashboard Admin}

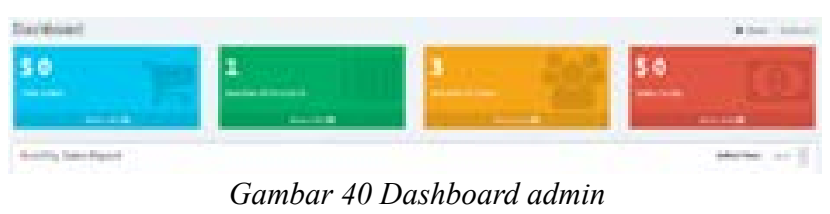

Berdasarkan Gambar 40, tampilan dashboard admin yang berisi menu seperti sales untuk penjualan dan product untuk melihat dan menambah produk.

\section{SIMPULAN}

Pada penelitian ini dihasilkan Sistem Informasi E-Commerce Spare Parts Mobil pada Toko Aneka Jaya Motor berbasis Website yang dapat membantu pelanggan melakukan transaksi/pembelian barang secara online tanpa harus datang ke toko langsung. Metode pengembangan sistem dengan Waterfall sesuai digunakan dalam penelitian ini karena sesuai dengan apa yang pemilik toko inginkan. Pemodelan visual menggunakan Unified Modelling Language membantu peneliti untuk menggambarkan karakteristik sistem secara lebih detail dalam membuat rancangan. Pengujian blackbox membantu peneliti untuk mngevaluasi yang dibangun karena di dasari pada kebutuhan fungsional sistem yang sesuai dengan pengembangan sistem.

\section{DAFTAR RUJUKAN}

[1] T. Sutabri, "Konsep Dasar Sistem Informasi," in Konsep Sistem Informasi, I. Nastiti, Ed., Yogyakarta, CV ANDI OFFSET, 2012, p. 46. 
[2] T. Sutabri, "Konsep E-Commerce," in Konsep Sistem Informasi, I. Nastiti, Ed., Yogyakarta, CV ANDI OFFSET, 2012, pp. 108-109.

[3] M. M. Ranatarisza and M. A. Noor, "Flowchart," in SISTEM INFORMASI AKUNTANSI : Aplikasi Pada Administrasi Bisnis, Malang, Universitas Brawijaya Press (UB Press), 2013, pp. 86-87.

[4] M. Muslihudin and Oktafianto., "Analisis dan Perancangan Sistem Informasi Menggunakan Model Terstruktur dan UML,” Yogyakarta, ANDI, 2016, pp. 58-59.

[5] A. Widayanto and I. U. Wardati, "Perancangan Sistem Informasi Penjualan Spare Part Mobil Pada Bengkel Samsi Motor Pacitan," Indonesian Journal on Networking and Security, pp. 1-7, 2013.
[6] C. Muallifah, B. E. Purnama and Sukadi. , "Sistem Informasi Penjualan Barang Pada Bengkel Karunia Motor Arjosari," Journal Speed-Sentra Penelitian Engineering dan Edukasi, vol. 8, no. 2, pp. 1-16, 2016.

[7] N. Setiadi and R. Setiawan, "Pengembangan Aplikasi Penjualan Sparepart di Bengkel Anugrah Jaya Motor Berbasis Desktop," Jurnal Algoritma Sekolah Tinggi Teknologi Garut, vol. 13, no. 1, pp. 1-8, 2016.

[8] S. Kosasi, "Perancangan Sistem E-Commerce Untuk Memperluas Pasar Produk Oleh-Oleh Khas Pontianak," pp. 1-10, 2015.

[9] A. G. Khan, "Electronic Commerce: A Study on Benefits and Challenges in an Emerging Economy," Global Journals Inc., 
Kalbiscentia, Jurnal Sains dan Teknologi, Volume 7, No. 1, Februari 2020 